\author{
Kázmér KLÁra \\ Nyitrai Konstantin Filozófus Egyetem \\ klari.kazmer@gmail.com
}

\title{
ÍROTT SZÖVEGEK MEGÉRTÉSE KOMÁROMI MAGYAR GIMNAZISTÁK KÖRÉBEN ${ }^{1}$
}

\section{Bevezetés}

Az iskolai oktatás egyik fó célja az, hogy a diákok az oktatás során olyan anyanyelvi szövegértési kompetenciákra tegyenek szert, amelyek birtokában sikeresen helyt tudnak állni a mindennapokban különböző írott szövegek megértésekor és értelmezésekor. A szlovákiai oktatásban sincs ez másképp, hiszen a hivatalos oktatási dokumentumok ismertetik évfolyamonkénti bontásban az általános iskola első évétől egészen a középiskolai oktatás végéig, hogy a tanulóknak milyen szövegértési kompetenciákkal kellene rendelkezniük az iskolai képzés bizonyos szintjein. Az egyes nemzetközi felmérések (pl. PISA) eredményeiből viszont tudjuk, hogy nem mindegyik tanuló tudja elsajátítani az elöírt követelményeket, és szövegértési képességeikben hiányosságok tapasztalhatóak, amelyek a szövegek sikertelen megértéséhez és értelmezéséhez vezethetnek (l. pl. Jánk 2017). Mindenképpen fontos lenne a diákok szövegértési képességének szintjének feltérképezése, hogy a tanulók szövegértési kompetenciái fejleszthetők legyenek. A szövegértési képességek fejlesztésének céljából munkámban a szlovákiai magyar középiskolás tanulók (gimnazisták és szakközépiskolások) anyanyelvi szövegértési képességeit mérem fel és értékelem. Jelen tanulmányban a szövegértési kutatásom részeredményeit mutatom be a komáromi gimnázium elsős és negyedikes diákjai szövegértési eredményein keresztül.

\section{A szöveg fogalma}

A szöveg a kommunikáció, vagyis az ismeretátadás és ismeretszerzés alapegysége (Tolcsvai Nagy 2001: 7). A szöveg fogalmának nincs egységes meghatározása, definiálása attól függ, hogy milyen szempontból közelítjük meg. A 80-as évektől a szöveg tanulmányozásával kapcsolatban a kognitív folyamatok kerültek elötérbe, és a mai szövegkutatások a szöveget kognitív keretben igyekeznek leírni (Tolcsvai Nagy 2001: 36-37), ezáltal túlmutatva csupán a mondatok nyelvtani kapcsolatainak a meghatározásán. Ez a megközelítés nem különíti el egymástól élesen az egyén nyelvhasználati tudását és a nyelvről szóló ismereteket, hanem a kettőt együtt kezeli (Zs. Sejtes 2018: 245). Ebből

1 A tanulmány az 1/0170/18/ 12 számú VEGA projekt keretében valósult meg. 
a szemléletből kiindulva munkámban a kognitív szempont alapján közelítem meg a szöveg és a szövegértés fogalmát és jellemzőit.

Michael Halliday meghatározása szerint ha az emberek beszélnek vagy írnak, szövegeket hoznak létre. A szöveg egy nyelv kontextusbeli működése, ugyanis Halliday szerint a nyelv az értelemalkotás egyik forrása, a szöveg pedig az értelem kontextusbeli megalkotásának a folyamata (Halliday 2014: 3). A szöveg nem csupán egymást követő mondatok sorozata, mert a szöveget alkotó nyelvi elemek eltérő funkciókat töltenek be, és ezek kölcsönösen hozzáadódnak a szöveghez (Tolcsvai Nagy 2006: 150). BeaugrandeDressler (2000) szövegfelfogása szerint a „szöveg minden olyan közlés, amely a szövegszerűség hét ismérvének eleget tesz" (Beaugrande-Dressler 2000: 23). A szerzőpáros szerint ha a hét ismérv közül akár egy nem teljesül, abban az esetben a szöveg nem lesz közlésre alkalmas. Az említett szövegfelfogás alapján az ilyen szöveg nem tekinthető szövegnek. A szerzők szerint a hét ismérv a következő (Beaugrande-Dressler 2000: 19-36):

1. a kohézió - a szövegfelszín elemeinek grammatikai összefüggése;

2. a koherencia - a szövegfelszín alatti fogalmak és viszonyok közötti összetartó erő;

3. a szándékoltság - a szöveg megalkotójának igyekezete arra vonatkozóan, hogy a létrehozott szöveg kohézióval és koherenciával rendelkezzen, továbbá teljesíteni tudja a közlés célját;

4. az elfogadhatóság - a szöveget megértő személy szöveggel kapcsolatos hozzáállására utal. Pl. koherens-e az adott szöveg a befogadó számára;

5. a hírérték - a szövegben levő közlés ismert vagy ismeretlen, illetve várt vagy váratlan voltára vonatkozik;

6. a helyzetszerüség - azoknak az elemeknek az összessége, amelyek egy szöveget egy adott helyzetben relevánssá tesznek;

7. az intertextualitás - egy adott szöveg megértéséhez nélkülözhetetlen egyéb szövegek ismeretét jelenti.

\section{A szövegértés fogalma és szintjei}

„A mindennapi élet egymásba érő tevékenységei során folyamatosan hozunk létre, folytatunk és értünk meg különböző szövegeket, [...] azaz állandóan tapasztaljuk, hogy cselekvő és megértő részesei vagyunk egy színes, összetett szövegvilágnak" (Tolcsvai Nagy 2001: 10). A szövegértés fogalmát a RAND (Reading Study Group) (Snow 2002: 13) az írott szöveggel való interakción és együttmüködésen keresztüli jelentésalkotás és kivonatolás egyidejű folyamatának határozta meg. Ez a meghatározás kihangsúlyozza a szövegértés folyamatának számos jellegzetes összetevőjét: az írott szöveg dekódolását, a jelentés megalkotásának a folyamatát a szövegben ki nem mondott információ alapján, az olvasó aktív együttműködését a szöveggel stb. Paige-Smith (2018: 1) a művelt egyén egyik fö jellemzőjeként nevezi meg a szövegértéssel való olvasás képességét. Nouwens (2017) kihangsúlyozza a szövegértési képesség szerepének fontosságát az új 
információszerzésben. Mindez azt is jelenti, hogy az egyén számára elengedhetetlenül fontos a megfelelő szintű szövegértési képesség birtoklása és használata az iskolai oktatásban és azon kívül is. Ezért az iskolai oktatás első éveiben nagy hangsúly kerül az olvasás képességének megtanítására és az alapvető szövegértési képességek elsajátítására. Felső tagozattól változás következik be az oktatásban: a diákok nem olvasni tanulnak, hanem azért olvasnak, hogy tanuljanak (Nouwens 2017: 10). Hudson (2007) meghatározásában a szövegértés egy olyan képesség, amelynek segítségével az olvasó használni tudja az előzetes tudását és az olvasott szöveg kontextusát ahhoz, hogy saját maga számára megalkossa a szöveg jelentését, és ki tudja következtetni a szöveg folytatását. Az olvasási folyamat során a cél nem az egyes szavak/mondatok értelmének a megértése, hanem a szöveg mondanivalójának a megalkotása. A szövegértés egy komplex képesség, elsajátításához és a mindennapi életben való felhasználásához többféle tudás szükséges: a kognitív funkciók megfelelő szintű fejlettsége, működése és együttműködése is (Woolley 2011: 15-16). Az OECD a PISA-felmérésekben a szövegértés képességét így határozza meg: „[...] az írott szövegek megértése, felhasználása és az ezekre való reflektálás annak érdekében, hogy az egyén elérje céljait, fejlessze tudását és képességeit, és hatékonyan részt vegyen a mindennapi életben (Vári et al. 2003: 35).” A nemzetközi felmérések a szövegértést a mindennapi életben való boldoguláshoz szükséges tényezőként határozták meg.

A szövegértési kompetencia különböző művelettípusait különbözteti meg a szakirodalom. Munkámban az OECD PISA felmérése által felállított szövegértési gondolkodási műveleteket használom, amelyek: a hozzáférés és a visszakeresés, az értelmezés és az integráció, a reflexió és az értékelés. Ezek a műveletek kölcsönösen függenek egymástól.

- A hozzáférés és visszakeresés műveletekor az olvasó információkat keres és gyüjt össze a szövegből. Ezt a műveletet nehezítheti többféle tényező, pl. az információk mennyisége, amelyet az olvasónak meg kell keresnie; továbbá, hogy az információ explicit vagy implicit.

- Az értelmezés és integráció művelete alatt a szöveg feldolgozását értjük. Az olvasónak alapvető összefüggéseket kell felismernie, mint például: rész és egész viszonyát, ok okozati összefüggéseket, következtetéseket kell megállapítania a szöveg egészével vagy egy részével kapcsolatban. Ezt a gondolati műveletet nagyban befolyásolja a szöveg hossza és az is, hogy az olvasó mennyire ismeri az adott szöveg témáját.

- A reflexió és értékelés műveletével az olvasó kapcsolatot hoz létre az elolvasott szöveg és meglévő előzetes tudása között, pl. saját véleményt alkot a szöveg témájával kapcsolatban (Balázsi et al. 2010: 29).

\section{A kutatás módszere}

A középiskolás diákok szövegértési kompetenciáit vizsgáló kutatásban összesen 13 középiskola (gimnázium, szakközépiskola, szakmunkásképző) 649 diákja vett részt: 328 elsős és 321 negyedikes. Azért választottuk ki a középiskolás tanulmányaikat elkezdő 
(14-15 éves diákok) és az érettségi vizsgára készülő diákok (18-19 éves tanulók) csoportját a kutatásban való részvételre, hogy a két korcsoport szövegértési képességei közötti esetleges különbségeket is fel tudjuk fedni. Jelen tanulmányban egy délnyugat-szlovákiai város magyar tanítási nyelvű gimnáziumának diákjainak a szövegértési eredményeit mutatom be. A felmérésben részt vevő tanulók számát az adott iskolák évfolyamainak maximális diákszáma határozta meg. A tanulók mindegyike egy szociológiai kérdőívet és egy szövegértési tesztet töltött ki. A kérdőívben a diákokra vonatkozó alapadatokon kívül (nem, lakhely) olyan információkra kérdeztünk rá, amelyek hatással lehetnek a tanulók szövegértési teszten elért eredményeire (nyelvhasználat, olvasási szokások). A szövegértési tesztet a 2009-es PISA-tesztelés nyilvánosságra hozott feladatai alapján állítottuk össze többek között azért, mert a szlovákiai PISA-tesztelés eredményein keresztül rendelkezünk információval a 15 éves tanulók szövegértési kompetenciáinak szintjéről. A már meglévő adatok így összehasonlíthatók saját eredményeinkkel, s választ kapunk arra a kérdésre is, hogy milyen mértékben változik a tanulók szövegértési képessége az életkoruk előrehaladtával. A felmérés számára elkészített teszt tartalmaz három szöveget (egy folyamatosat és két nem folyamatosat) és a hozzá kapcsolódó feladatokat. Az alábbiakban a diákok eredményeit mutatom be az egyik nem folyamatos szöveghez és feladataihoz ${ }^{2}$ kapcsolódóan.

\section{Eredmények}

A továbbiakban a diákok eltérő eredményeit elemzem a két vizsgált korcsoportban, a kisszámú minta miatt a nemek különböző szövegértési eredményének a részletes elemzésére ebben az írásban nem térek ki. A diákok szövegértési képességei részletes bemutatásához az átlageredményeket közlöm, a különbségek közötti eltérések feltérképezéséhez kétmintás t-próbát alkalmaztam. Ismertetem a szociológiai kérdőív adatait, majd a diákok szövegértési eredményeinek a bemutatása következik.

\subsection{A szociológiai kérdőív adatainak ismertetése}

A kiválasztott gimnázium a délnyugat-szlovákiai Komárom városban található. Az iskolából 75 tanuló: 37 elsős és 38 negyedikes diák vett részt a felmérésben, a résztvevők létszáma a két kiválasztott évfolyamban megközelítőleg kiegyenlített volt.

A kérdőívben a tanulók válaszoltak a nyelvhasználatukkal kapcsolatos kérdésre is: Milyen nyelven beszélnek veled szüleid és környezeted többsége születésed óta? A diákok a következő megadott válaszlehetőségek közül - magyarul, szlovákul, magyarul és szlovákul, egyéb - választhatták ki a rájuk vonatkozóan megfelelő választ. Az adatok (lásd bővebben: 1. táblázat) azt mutatják, hogy a kutatásban résztvevő diákok többségével $(90,6 \%)$ a kérdésben megnevezett személyek magyarul beszéltek, és csupán a tanulók

2 Lásd: 1. melléklet, internetes forrás: W1. 
9,3\%-val kommunikáltak a családtagok magyarul és szlovákul is. Az adatokból kiderült, hogy kizárólag a szlovák nyelvet a mindennapi kommunikáció során egyik tanulóval sem használták.

\begin{tabular}{|l|l|l|l|}
\hline \multicolumn{1}{|c|}{ Komárom } & \multicolumn{1}{c|}{ Elsősök } & \multicolumn{1}{c|}{ Negyedikesek } & \multicolumn{1}{c|}{ Összesen } \\
\hline magyar & $34(91,9 \%)$ & $34(89,5 \%)$ & $68(90,6 \%)$ \\
\hline magyar és szlovák & $3(8,1 \%)$ & $4(10,5 \%)$ & $7(9,3 \%)$ \\
\hline
\end{tabular}

1. táblázat: Milyen nyelven beszélnek veled szüleid és környezeted többsége születésed óta?

A diákok a saját nyelvtudásukat szintén egy zárt végű kérdés megadott lehetőségeinek a bekarikázásával értékelhették. Összességében a diákok nagy része - saját bevallásuk szerint - sokkal jobban tud magyarul, mint szlovákul, ezt a választ karikázta be 67 tanuló (89,3\%). A diákok egyike sem érzi úgy, hogy jobban beszélne szlovákul, mint magyarul. A részletes eredményeket a 2 . táblázat összegzi.

\begin{tabular}{|l|l|l|l|}
\hline \multicolumn{1}{|c|}{ Komárom } & \multicolumn{1}{|c|}{ Elsősök } & Negyedikesek & \multicolumn{1}{|c|}{ Összesen } \\
\hline $\begin{array}{l}\text { sokkal jobban tudok magyarul, } \\
\text { mint szlovákul }\end{array}$ & $34(91,9 \%)$ & $33(86,8 \%)$ & $67(89,3 \%)$ \\
\hline $\begin{array}{l}\text { valamivel jobban tudok magyarul, } \\
\text { mint szlovákul }\end{array}$ & $2(5,4 \%)$ & $4(10,5 \%)$ & $6(8 \%)$ \\
\hline $\begin{array}{l}\text { nagyjából egyformán tudok magya- } \\
\text { rul és szlovákul }\end{array}$ & $1(2,7 \%)$ & $1(2,6 \%)$ & $2(2,6 \%)$ \\
\hline Összesen & $37(100 \%)$ & $38(100 \%)$ & $75(100 \%)$ \\
\hline
\end{tabular}

2. táblázat: A diákok magyar- és szlováknyelv-tudása

A kérdőívben nemcsak az adatközlők nyelvhasználatára és nyelvtudására kérdeztünk rá, hanem arra is, hogy a tanulók milyen érdemjegyet ${ }^{3}$ kaptak a legutolsó év végi bizonyítványban magyar nyelv és irodalom tantárgyból. Ha megnézzük a kapott adatokat évfolyamonkénti bontásban (3. táblázat), látjuk, hogy az elsősök többsége: 86,5\%-a egyest szerzett a már megnevezett tantárgyból, míg a negyedikeseknek csupán az 50\%-a érte el ugyanezt az értékelést. Továbbá a legrosszabb jegy, amit a mintában szereplő diákok kaptak,

3 A szlovákiai oktatásban a tanulók értékelése jeggyel történik egy ötfokozatú skálán, ahol az egyes a legjobb jegy, az ötös pedig a legrosszabb kapható jegy. 
a hármas volt, és csupán az adatközlők 8\%-a tartozik ebbe a csoportba. Mivel a tanulók nagyon jó eredményekkel rendelkeznek a magyar nyelv és irodalom tantárgyból, feltételezhető, hogy megfelelő szintű anyanyelvi szövegértési képességekkel rendelkeznek.

\begin{tabular}{|l|l|l|l|}
\hline \multicolumn{1}{|c|}{ Komárom } & \multicolumn{1}{c|}{ Elsősök } & \multicolumn{1}{c|}{ Negyedikesek } & \multicolumn{1}{c|}{ Összesen } \\
\hline egyes & $32(86,5 \%)$ & $19(50 \%)$ & $51(68 \%)$ \\
\hline kettes & $3(8,1 \%)$ & $14(36,8 \%)$ & $17(22,6 \%)$ \\
\hline hármas & $2(5,4 \%)$ & $4(10,5 \%)$ & $6(8 \%)$ \\
\hline Összesen & $37(100 \%)$ & $37(97,4 \%)$ & $74(98,6 \%)$ \\
\hline
\end{tabular}

3. táblázat: A diákok érdemjegyei magyar nyelvből és irodalomból

A nemzetközi szövegértési felmérések eredményei (pl. PISA) alapján tudjuk, hogy a családi háttér az egyik lehetséges változó, amely befolyásolhatja a diákok szövegértési kompetenciájának a szintjét. A kérdőív kitöltésekor a diákok 6 megadott kategória ${ }^{4}$ egyikébe sorolhatták be szüleik legmagasabb elért végzettségét. A kapott válaszokat az édesanyák esetében a 4. táblázat, míg az édesapákra vonatkozó adatokat az 5. táblázat összegzi.

\begin{tabular}{|l|l|l|l|}
\hline \multicolumn{1}{|c|}{ Komárom } & \multicolumn{1}{c|}{ Elsősök } & \multicolumn{1}{c|}{ Negyedikesek } & \multicolumn{1}{c|}{ Összesen } \\
\hline általános iskola & - & - & - \\
\hline szakmunkásképző & $1(2,7 \%)$ & $1(2,6 \%)$ & $2(2,6 \%)$ \\
\hline szakközépiskola & $14(37,8 \%)$ & $8(21 \%)$ & $22(29,3 \%)$ \\
\hline gimnázium & $5(13,5 \%)$ & $5(13,1 \%)$ & $10(13,3 \%)$ \\
\hline $\begin{array}{l}\text { egyetem, föiskola } \\
\text { posztgraduális } \\
\text { képzés }\end{array}$ & - & $23(60,5 \%)$ & $39(52 \%)$ \\
\hline Összesen & $36(97,3 \%)$ & $16 \%)$ & $1(1,3 \%)$ \\
\hline
\end{tabular}

4. táblázat: A tanulók édesanyáinak a végzettsége

4 A választási lehetőségek a következők voltak: általános iskola; szakmunkásképző; szakközépiskola; gimnázium; egyetem, főiskola; posztgraduális képzés. 


\begin{tabular}{|l|l|l|l|}
\hline \multicolumn{1}{|c|}{ Komárom } & \multicolumn{1}{c|}{ Elsősök } & \multicolumn{1}{c|}{ Negyedikesek } & \multicolumn{1}{c|}{ Összesen } \\
\hline általános iskola & $1(2,7 \%)$ & - & $1(1,3 \%)$ \\
\hline szakmunkásképző & $6(16,2 \%)$ & $4(10,5 \%)$ & $10(13,3 \%)$ \\
\hline szakközépiskola & $12(32,4 \%)$ & $10(26,3 \%)$ & $22(29,3 \%)$ \\
\hline gimnázium & $2(5,4 \%)$ & $2(5,3 \%)$ & $4(5,3 \%)$ \\
\hline egyetem, föiskola & $14(37,8 \%)$ & $22(57,9 \%)$ & $36(48 \%)$ \\
\hline $\begin{array}{l}\text { posztgraduális } \\
\text { képzés }\end{array}$ & - & - & - \\
\hline Összesen & $35(94,6 \%)$ & $38(100 \%)$ & $73(97,3 \%)$ \\
\hline
\end{tabular}

5. táblázat: A tanulók édesapáinak a végzettsége

A szülők végzettségére vonatkozó 6 kategóriát az elemzés során 3 csoportba soroltam be:

- érettségivel nem rendelkezők: általános iskolai vagy szakmunkásképzői végzettséggel rendelkező szülők;

- érettségivel rendelkezők: szakközépiskolában vagy gimnáziumban tanult szülők;

- felsőfokú végzettségűek: egyetemet vagy főiskolát végzett illetve posztgraduális képzésben tanuló szülők.

Az adatok összesítését követően a következők jellemzőek az elsős és negyedikes tanulók szüleinek a végzettségére:

- nem rendelkezik érettségivel az édesanyák közül 2 személy (2,6\%), az édesapákból pedig 11-en (14,6\%);

- érettségi vizsgával záruló tanulmányokat végzett 32 édesanya (42,6\%) és 26 édesapa $(34,6 \%)$;

- felsőfokú végzettséggel rendelkezik 40 édesanya (53,3\%) és 36 édesapa (48\%).

Az adatokból látjuk, hogy a diákoknak megközelítőleg a fele értelmiségi családból származik, hiszen vagy az egyik vagy mindkét szülőknek egyetemi végzettsége van, így ebből az adatból kiindulva is feltételezzük a diákok szövegértési teszten elért jó eredményeit.

A kérdőív egy következő kérdésénél a diákok jellemezték saját olvasási szokásaikat. A tanulók adott időtartamokhoz ${ }^{5}$ csoportosíthattak különböző szövegeket az alapján, hogy milyen gyakorisággal olvassák őket. A diákok a kérdés megválaszolása során

5 Naponta 10-30 percet, naponta 1-2 órát vagy többet, hetente 10-30 percet, hetente 1-2 órát vagy többet, heti 1-2 hosszabb szöveget, havi 1-2 hosszabb szöveget. 
többféle típusú szöveget is megjelölhettek. A 6. táblázat mutatja, hogy a tanulók milyen szövegeket olvasnak napi 1-2 órában vagy többen.

\begin{tabular}{|l|l|l|l|}
\hline \multicolumn{1}{|c|}{ Komárom } & \multicolumn{1}{c|}{ Elsősök } & \multicolumn{1}{c|}{ Negyedikesek } & \multicolumn{1}{c|}{ Összesen } \\
\hline áruházak prospektusai & $1(2,7 \%)$ & - & $1(1,3 \%)$ \\
\hline $\begin{array}{l}\text { nyomtatott újságok, } \\
\text { magazinok }\end{array}$ & $1(2,7 \%)$ & $1(2,6 \%)$ & $2(2,6 \%)$ \\
\hline ismeretterjesztő irodalom & $2(5,4 \%)$ & $5(13,1 \%)$ & $7(9,3 \%)$ \\
\hline szépirodalom & $12(32,4 \%)$ & $12(31,6 \%)$ & $24(32 \%)$ \\
\hline tankönyvek & $14(37,8 \%)$ & $11(28,9 \%)$ & $25(33,3 \%)$ \\
\hline blog, közösségi oldal & $18(48,6 \%)$ & $20(52,6 \%)$ & $38(50,6 \%)$ \\
\hline
\end{tabular}

6. táblázat: A naponta 1-2 órát vagy többet olvasó diákok olvasási szokásai

A diákoknak megközelítőleg a fele közösségi oldalak, blogok olvasásával tölt naponta 1-2 órát vagy többet. Ezzel szemben a megkérdezettek egyharmada olvas csupán szépirodalmat vagy tankönyvi szövegeket. Az adatok azt mutatják, hogy az adatközlők a közösségi oldalak szövegei olvasásának a javára hanyagolják az egyéb típusú szövegek olvasását, pl. a korukhoz mérten nem olvasnak (tanulnak) naponta gyakran tankönyvi szövegeket és ismeretszerzés vagy szórakozás céljából is keveset olvasnak (pl. szépirodalmi vagy ismeretterjesztő szövegeket).

Összességében a mintában szereplő diákokról megtudtuk, hogy nyelvhasználatukra és nyelvtudásukra a magyar nyelv dominanciája jellemző. A tanulók többsége a magyar nyelv és irodalom tantárgyból kapott érdemjegyek alapján feltételezhetően kitűnő anyanyelvi képességekkel rendelkezik, és a magyar nyelvet magas szinten ismeri és használja szóban és írásban egyaránt. A diákoknak megközelítőleg a fele értelmiségi családból származik, amelyben vagy az egyik vagy mindkét szülő felsőfokú végzettséggel rendelkezik. A tanulókról ismertetett információk alapján feltételezzük, hogy a tesztet kitöltők nagyobb része helyesen oldja meg a tesztfeladatok mindegyikét.

\subsection{A tesztszöveg és feladatainak ismertetése}

Tanulmányomban komáromi magyar gimnazisták szövegértési kompetenciáit mutatom be egy nem folyamatos tesztszöveg (áruházi útmutató) feladataihoz kapcsolódóan. E nagyon rövid szöveg célja a vásárlók tájékoztatása az adott termékről. A szöveg típusa útmutató. Közli, hogy mit kell tenni abban az esetben, ha valaki vásárolt a megadott termékből, és mogyoróallergiája van. 
A tesztszöveghez kapcsolódó 1. kérdés: Mi a közlemény célja? A négy lehetőség közül az elvárt válasz a C (Hogy figyelmeztesse a vásárlókat a keksszel kapcsolatban). Ennek a kérdésnek a sikeres megválaszolásához a tanulóknak az értelmezés és integráció szövegértési gondolkodási műveletet kellett alkalmazniuk. Összesen 71 (94,6\%) helyes válasz érkezett, az első évfolyamba járó diákok közül 36 (97,3\%), a negyedikesekből 35 (92,1\%) tanuló válaszolt helyesen. Az elsősök és a negyedikesek megközelítőleg azonosan magas arányban adtak helyes választ az első kérdésre, és a teljesítményük közötti különbség nem szignifikáns.

A 2. kérdés: Mi a kekszet elöállitó cég neve? Ez a kérdés nyílt végü volt, és egy szövegbeli explicit információ megnevezését igényelte a válaszadóktól. Helyesek voltak azok a válaszok, amelyekben a diákok leírták, hogy a keksz gyártója a Fine Foods Kft. A tanulók a kérdés megválaszolásához a hozzáférés és visszakeresés szövegértési gondolkodási műveletet alkalmazták. A második kérdésre 73-an (97,3\%) adtak helyes választ, 37 (100\%) elsős és $36(94,7 \%)$ negyedikes. Ennél a kérdésnél is az elsős és a negyedikes diákok többsége helyesen válaszolt. A különböző korú tanulók eredménye közötti eltérések minimálisak, nem szignifikánsak.

A 3. kérdés a következő volt: Mit tennél, ha te is vásároltál volna a kekszböl? Miért ezt tennéd? Válaszod alátámasztásához hivatkozz a szövegben található információkra!

Erre a kérdésre a válaszadóknak egy rövid választ kellett adniuk, melyben leírták, hogy ha vettek volna az adott termékből, akkor mit tettek volna. Válaszukat nemcsak megadni kellett, hanem indokolni is, vagyis a válaszadóknak reflektálniuk és értékelniük kellett. Ebből kifolyólag helyes válasznak azok a megoldások tekinthetőek, amelyekben a válaszadó hivatkozik a szövegben található információ egyikére (pl. a vásárló érdeklődhet a megadott telefonszámon vagy a vásárlás helyén visszaválthatja a terméket illetve, ha nem allergiás a mogyoróra, akkor a figyelmeztetés nem neki szól, így a kekszet el is fogyaszthatja). A kitöltőkből 53-an (70,6\%) adtak helyes választ: 24 (64,8\%) elsős és 29 $(76,3 \%)$ negyedikes, a teljesítményük közötti különbség nem szignifikáns. Az alábbiakban mutatunk néhányat a helyes megoldások közül (1):

(1)

a. Megenném. Mert nem vagyok a mogyoróra allergiás.

b. Visszavittem volna, mert a teljes árát visszafizetik.

c. Visszavinném, mert levan írva az áruházi közleményben is, hogy így járunk el.

d. Én elfogyasztottam volna, mert nem vagyok allergiás a mogyoróra.

A helytelen válaszolók válaszaiból néhány példa a következőkben olvasható (2).

(2)

a. Nem ettem volna meg, mert paleo diétán vagyok, nem fogyasztok kekszet + lejárt, ha jól értem. 
b. Valószínủleg nem ettem volna meg, mert februárban már lejárt.

c. Megenném, mivel pénzt adtam ki érte, szeretem, és nem túl hosszú a szavatossági ideje.

d. Megenném mind az ökör, mert olyan emésztőrendszerem van, hogy nem érdekli mit kap.

Mint ahogyan a példák mutatják, a válaszok között voltak az adott tárgy szempontjából irreleváns válaszok, és helytelen információkat tartalmazók.

A 4. kérdés: Miért szerepelnek a közleményben a „Minöségét megörzi” dátumok? Helyesen válaszoltak erre a kérdésre azok, akik válaszukba belefoglalták azt, hogy az adott időpontok pontosítják, hogy mely termékek tartalmazhatnak mogyorót. Erre a kérdésre a diákok jelentős része nem tudott helyesen válaszolni. Helyes választ a 75 tanulóból mindösszesen 12-en (16\%) adtak. Közülük 2-en (5,4\%) elsősök és 10-en (26,3\%) negyedikesek. A különböző korú diákok teljesítménye ennél a kérdésnél szignifikánsan különbözött egymástól. Azok, akik helyesen válaszoltak erre a kérdésre, az alábbi válaszokat adták (3):

(3)

a. Amik akkor járnak le, mogyorót tartalmaznak, és nincs feltüntetve sehol.

b. Mert így lehet megtudni, a mi általunk vásárolt termékről van-e szó.

c. Mert a fent említett időpontokban lejáró kekszek tartalmaznak mogyorót.

Ezekkel a válaszokkal ellentétben a többi tanuló nem értelmezte helyesen a kérdést, és feltételezhetően a minőségét megőrzi dátumok láttán a diákok rögtön azt írták le a válaszaikban, hogy ezek a dátumok a fogyaszthatóság időpontját jelölik. Ez az állításuk igaz is lenne, ha a kérdésben a kekszen szereplő dátumokra kérdeztünk volna rá, de ez nem így volt, hiszen a közleményen szereplő dátumok célját kellett megmagyarázni. Ezeken a típusú válaszokon kívül a diákok nagy többsége adott meg különféle típusú irreleváns vagy helytelen információkat (4):

(4)

a. Kétszer is legyártották egymás után a hibás címkéjű terméket, így különböző időpontban járnak le.

b. Azért, hogy tudják az emberek, meddig lesz még ez a keksz a boltban.

c. Mert nem tudják, hogy a rövidebb reklámok hatásosabbak.

d. Mivel a megjelent hírdetéskor ezek a kekszek lejártak voltak.

A tesztfeladat mindegyik kérdésére az elsős tanulók közül 2 személy (2,6\%), míg a negyedikesek közül 9 diák (12\%) felelt helyesen. 


\section{6. Összegzés}

A tanulmányban 75 gimnazista diák szövegértési teszten elért eredményeit mutattam be. Az elsős tanulók eredményeit a 7. táblázat foglalja össze, míg a negyedikesekét a 8. táblázatban összegeztem.

\begin{tabular}{|c|c|c|c|c|}
\hline Komárom & 1. kérdés & 2. kérdés & 3. kérdés & 4. kérdés \\
\hline Összesen & $36(97,3 \%)$ & $37(100 \%)$ & $24(64,8 \%)$ & $2(5,4 \%)$ \\
\hline
\end{tabular}

7. táblázat: A helyesen válaszoló elsős tanulók aránya nemek szerint az Áruházi közlemény c. szöveg négy kérdésére

\begin{tabular}{|c|c|c|c|c|}
\hline Komárom & 1. kérdés & 2. kérdés & 3. kérdés & 4. kérdés \\
\hline Összesen & $35(92,1 \%)$ & $36(94,7 \%)$ & $29(76,3 \%)$ & $10(26,3 \%)$ \\
\hline
\end{tabular}

8. táblázat: A helyesen válaszoló negyedikes tanulók aránya nemek szerint az Áruházi közlemény c. szöveg négy kérdésére

A négy kérdés helyes megválaszolásához a diákoknak különböző szövegértési gondolkodási műveleteket kellett alkalmazniuk:

- a hozzáférés és visszakeresés műveletét alkalmazták a második kérdés megválaszolásánál;

- az értelmezés és integráció műveletét használták az első és a negyedik kérdés megválaszolásakor;

- a reflexió és értékelés szövegértési művelet alkalmazását a harmadik kérdés igényelte.

A mintában szereplő gimnazista diákok szövegértési eredményei hasonlóságokat mutatnak a 15 éves tanulók PISA-teljesítményével. A válaszok elemzése után kijelenthető, hogy az elsős és negyedikes gimnazista diákok is átlagosan a legegyszerübb gondolkodási müvelet használatát igénylö kérdést válaszolták meg a legtöbben helyesen. Az értelmezés és integráció műveletének használatakor szignifikáns különbség tapasztalható az első és a negyedik kérdésre adott válaszok eredménye között. Ennek a különbségnek a magyarázata lehet egyrészt az is, hogy az első kérdés feleletválasztós volt, míg a negyedik kérdésnél a tanulóknak saját választ kellett megfogalmazniuk. Másrészt az eredményeket indokolhatja az is, hogy a diákok az iskolai oktatás során kevés ilyen típusú szöveggel foglalkoznak. Legkevesebben helyesen a harmadik és negyedik kérdésre válaszoltak, amelyeknél a saját válaszukat kellett néhány mondatban leírniuk. A diákok szövegértési kompetenciái a bemutatott szociológiai adatok ismeretében gyengének tekinthetők. 
A tanulók szövegértési képességeit az iskolai oktatás nem fejleszti kellőképpen, és ennek az egyik következményeként a diákok nem tudnak helyesen rövid szövegeket sem értelmezni, sem a saját véleményüket kifejezni az olvasottakkal kapcsolatban. Az eredmények ismeretében mindenképpen fontos lenne, hogy a diákok a tanítási órák nagy részében ne csak hosszú folyamatos szövegeket olvassanak, hanem rövid nem folyamatos szövegeket is. Továbbá a tények visszamondásának megkövetelése mellett ugyan olyan nagy hangsúlyt kellene fektetni arra, hogy a tanulóknak legyen saját véleményük és meg tudják fogalmazni azt.

\section{Irodalom:}

Balázsi Ildikó - Ostorics László - Schumann Róbert - Szalay Balázs - Szepesi Ildikó 2010. A PISA 2009 tartalmi és technikai jellemzöi. Budapest: Oktatási Hivatal.

De Beaugrande, Robert - Dressler, Wolfgang 2000. Bevezetés a szövegnyelvészetbe. Budapest: Corvina Kiadó.

Halliday, Michael A. K. 2014. Halliday's Introduction to Functional Grammar (4th ed.). Routledge. London. New York. https://doi.org/10.4324/9780203783771

Hudson, Thom 2007. Teaching second language reading. Oxford: Oxford University Press. Jánk István 2017. Mi az a PISA-sokk, és mi ez a sok felhajtás körülötte? Nyelv és Tudomány. https://m.nyest.hu/hirek/mi-az-a-pisa-sokk-es-mi-ez-a-sok-felhajtas-korulotte (2019. 02. 14.)

Nouwens, Suzan 2017. Executive Functioning in Children's Reading Comprehension Development. Enschede: Gildeprint Drukkerijen.

Paige, David D. - Smith, Grant S. 2018. Academic vocabulary and reading fluency: Unlikely bedfellows in the quest for textual meaning. Education Sciences 8: 165. https://doi.org/10.3390/educsci8040165

Snow, Catherine E. 2002. Reading for Understanding: Toward an R\&D Program in Reading Comprehension. SantaMonica, CA: RAND.

Tolcsvai Nagy Gábor 2001. A magyar nyelv szövegtana. Budapest: Nemzeti Tankönyvkiadó.

Tolcsvai Nagy Gábor 2006. Szövegtan. In: Kiefer Ferenc (szerk.): Magyar nyelv. Budapest: Akadémiai Kiadó. 149-174.

Vári Péter - Bánfi Ilona - Szabó Annamária - Szalay Balázs 2003. PISA-vizsgálat 2000. Budapest: Műszaki Könyvkiadó.

Woolley, Gary 2011. Reading comprehension: Assisting children with learning diffculties, Springer Science+Business Media B. V. https://doi.org/10.1007/978-94-007-1174-7_1

Zs. Sejtes Györgyi 2018. Szövegről szövegre tanárjelölteknek kognitív, funkcionális, pragmatikai keretben. In: Karlovitz János Tibor (szerk.): Elmélet és gyakorlat a neveléstudományok és szakmódszertanok köréböl. Komárno, Slovakia: International Research Institute sro. 242-247. 


\section{Internetes hivatkozások}

W1 = PISA 2009. Nyilvánosságra hozott feladatok szövegértésből. https://www.oktatas. hu/pub_bin/dload/kozoktatas/nemzetkozi_meresek/pisa/peldafeladatok/PISA_peldafeladatok_Szovegertes_2009.pdf (2017. 11. 04.)

\section{Melléklet:}

1. melléklet: Áruházi közlemény

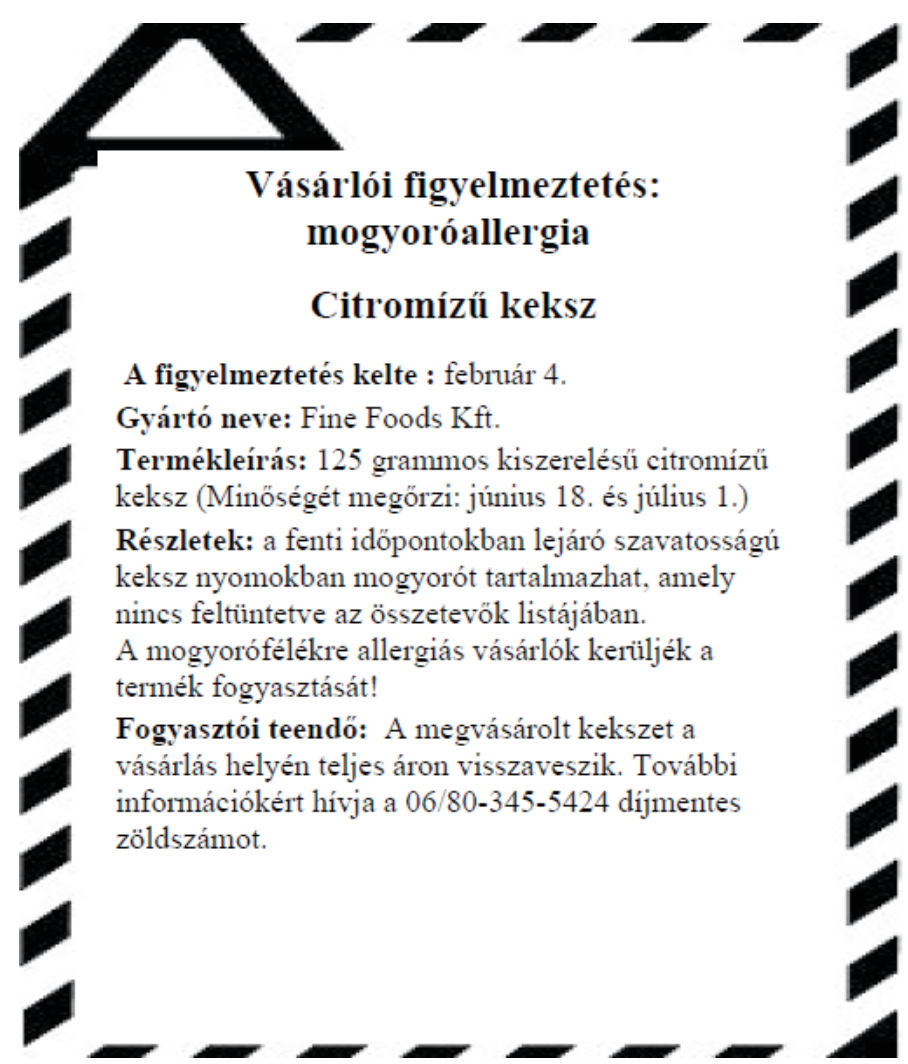


Az elözö oldalon látható közlemény egy élelmiszer-áruházban volt kifüggesztve.

A közlemény segitségével válaszolj az alábbi kérdésekre!

1. Mi a közlemény célja?

Hogy reklámozza a Citromízű kekszet.

Hogy tájékoztassa a vásárlókat a keksz előállításának időpontjáról.

Hogy figyelmeztesse a vásárlókat a keksszel kapcsolatban.

Hogy elmagyarázza a vásárlóknak, hol lehet megvásárolni a kekszet.

2. Mi a kekszet előállító cég neve?

3. Mit tennél, ha te is vásároltál volna a kekszből?

4. Miért ezt tennéd? Válaszod alátámasztásához hivatkozz a szövegben található információkra!

Miért szerepelnek a közleményben a „Minőségét megőrzi” dátumok? 